\title{
PROGNOSTIC ROLE OF SERUM URIC ACID FOLLOWING ACUTE MYOCARDIAL INFARCTION
}

\author{
Peddi Bhaskar1, Rajendra Prasad Parlapally2, Puduri Rajendra Prasad ${ }^{3}$
}

${ }^{1}$ Associate Professor, Department of General Medicine, KMC/MGM Hospital, Warangal, Telangana. ${ }^{2}$ Associate Professor, Department of General Medicine, KMC/MGM Hospital, Warangal, Telangana. 3 Postgraduate, Department of General Medicine, KMC/MGM Hospital, Warangal, Telangana.

\begin{tabular}{l}
\hline ABSTRACT \\
\hline BACKGROUND \\
Acute Myocardial Infarction (AMI) is the leading cause of mortality in both developed and developing countries.1,2 Acute coronary \\
syndromes are emerging out in epidemic proportions throughout the world. Factors contributing to death following acute \\
myocardial infarction are many.
\end{tabular}

Aims- To assess the prognostic significance of serum uric acid level in acute myocardial infarction and to assess the prognostic significance of serum uric acid levels with incidence of cardiac failure.

\section{MATERIALS AND METHODS}

This study was conducted in the Department of Medicine and Department of Cardiology, Mahatma Gandhi Memorial Hospital/Kakatiya Medical College, Warangal during the period from February 2013 to August 2014. Total number of patients included in this study were 100. There were 77 males, 23 female patients, age ranging from 42 years to 72 years.

\section{RESULTS}

The study population consisted of 100 patients with 77 males and 23 females. All patients belonged to places around Warangal District. All patients were admitted in Intensive Cardiac Care Unit initially for 5 days, then cared in adjoining intermediate cardiac care ward and discharged after an average period of 7 days provided there were no complications.

Total number of patients included in this study was 100, out of which 47 patients had elevated levels of uric acid above normal range and 53 patients had normal serum uric acid levels following acute myocardial infarction.

\section{CONCLUSION}

There is a significant association between elevated SUA and cardiac failure. Patients with high SUA level belonged to higher Killip class (III \& IV). Elevated uric acid level had an objective correlation with echocardiographic evaluation of LV dysfunction.

\section{KEYWORDS}

Uric acid, Prognosis, Mortality.

HOW TO CITE THIS ARTICLE: Bhaskar P, Parlapally RP, Prasad PR. Prognostic role of serum uric acid following acute myocardial infarction. J. Evolution Med. Dent. Sci. 2016;5(87):6447-6453, DOI: 10.14260/jemds/2016/1459

\section{BACKGROUND}

Acute Myocardial Infarction (AMI) is the leading cause of mortality in both developed and developing countries.1,2

Acute coronary syndromes are emerging out in epidemic proportions throughout the world. Factors contributing to death following acute myocardial infarction are many.

These factors relate mainly to electrical disturbances in the form of arrhythmia ${ }^{3}$ and mechanical disturbances in the form of pump failure. 4,5

Most sudden deaths in acute myocardial infarction occur within one hour due to ventricular fibrillation and also due to left ventricular failure when there is an extensive injury. ${ }^{6}$ Rest of the deaths following myocardial infarction occur within first one week and death cannot be predicted and occurs suddenly.

Financial or Other, Competing Interest: None.

Submission 21-07-2016, Peer Review 03-08-2016,

Acceptance 05-08-2016, Published 28-10-2016.

Corresponding Author:

Dr. Peddi Bhaskar,

Flat No. 303, Door No. 13-1-133,

Sai Towers, Matwada, Warangal.

E-mail: bhaskar_peddi2003@yahoo.co.in

DOI: $10.14260 /$ jemds/2016/1459
Hence, many trials have been conducted to identify markers that would be helpful to predict the risk of such adverse cardiac events.

Many trials have used serum Magnesium level, ${ }^{7}$ C-reactive protein levels, ${ }^{8}$ malonyl dialdehyde, ${ }^{9}$ white blood cell count ${ }^{9}$ as a predictor for mortality and morbidity following acute myocardial infarction and risk of developing adverse cardiac events like sudden cardiac death and congestive heart failure.

Previous studies have established that Serum Uric Acid (SUA) levels reflect circulating xanthine oxidase activity and oxidative stress production following acute myocardial infarction.

Free radicals produced in large amounts during myocardial ischaemia and reperfusion, take part in the degradation of cellular and subcellular membrane structures. The source of oxygen radicals in ischaemic myocardium are neutrophils recruited into the necrotic region as well as metabolic transformation of Hypoxanthine and Xanthine to Uric acid. ${ }^{9}$

Thus, it is evident that elevated Uric Acid (UA) levels is a good marker of oxidative stress and useful to assess the prognostic events in acute myocardial infarction.

This forms the basis of the study. 


\section{AIMS OF THE STUDY}

1. To assess the prognostic significance of serum uric acid level in acute myocardial infarction.

2. To assess the prognostic significance of serum uric acid levels with incidence of cardiac failure.

3. To validate the prognostic significance between quantitative serum uric acid level on admission and high Killip's class status in acute myocardial infarction.

4. To assess the prognostic significance of serum uric acid levels with incidence of short-term mortality.

\section{MATERIALS AND METHODS}

\section{Study Population}

This study was conducted in the Department of Medicine and Department of Cardiology, Mahatma Gandhi Memorial Hospital/Kakatiya Medical College, Warangal during the period from February 2013 to August 2014. Total number of patients included in this study were 100 . There were 77 males, 23 female patients, age ranging from 42 years to 72 years.

\section{Study Design}

This study is a prospective study. This study is aimed to assess the prognostic role of serum uric acid level following acute myocardial infarction and correlating the levels with shortterm complications.

This study included 100 patients of acute myocardial infarction of which patients who had a normal uric acid level were taken as a population with normal serum uric acid and the rest who had elevated uric acid level were taken up as a population with hyperuricaemia.

In both groups, the complications and short-term outcome were compared.

\section{Inclusion Criteria}

Patients with a diagnosis of acute ST Elevation Myocardial Infarction were entered into the study. A definite diagnosis of acute ST Elevation Myocardial Infarction was made if the patients satisfied the following criteria: A history of typical retrosternal compressive chest pain lasting for more than 30 minutes, not relieved by rest or nitrates. Typical ECG changes of acute ST Elevation Myocardial Infarction.

\section{Exclusion Criteria}

Patients with elevated renal parameters, Patients with Gout, Patients with history of chronic alcoholism, Patients with previous history of Ischaemic Heart Disease, Patients with diabetes mellitus, Patients on diuretic \& aspirin therapy.

Above patients were excluded because the coexisting disease or drug therapy might itself produce a high uric acid level.

Very late presentations of patients more than 72 hours also excluded since uric acid level tends to fall subsequently (Journal of the Indian Medical Association 1977 Sep. 1).

\section{Variables Recorded During the Study}

History, physical examination, routine laboratory investigations were performed in all subjects.

1. Presenting History

- Duration of chest discomfort.

- Associated symptoms like sweating, palpitations, breathlessness.

- Time of onset of symptoms.
2. Admission Electrocardiogram (ECG).

3. Killip's classification on admission.

4. Framingham criteria for congestive heart failure.

5. 2D echo cardiogram (left ventricular ejection fraction (LVEF)).

6. Laboratory Investigations.

- Complete blood picture.

- Random blood sugar, Serum lipid profile.

- Blood urea, Serum creatinine, Serum electrolytes.

- Serum uric acid level on admission.

- Urine albumin, sugar, deposits.

Qualifying patients received thrombolytic therapy with 1.5 million units of streptokinase followed by heparin for 5-7 days.

Assessment of left ventricular ejection fraction by echocardiography was performed either on day 4 or 5 of hospitalisation in most patients or earlier if clinically indicated.

\section{Uric Acid Estimation}

Immediately after admission, blood sample of $3 \mathrm{cc}$ was drawn by venepuncture and transferred to dry plain bottle and taken to biochemistry laboratory.

The method used for analysis is enzymatic method (Uricase method) by using autoanalyser.

In our laboratory, values taken as normal range.

\begin{tabular}{|c|c|c|c|}
\hline For Males & $:$ & 3.4 & $-7.0 \mathrm{mg} / \mathrm{dL}$ \\
\hline For Females & $:$ & 2.4 & $-6.0 \mathrm{mg} / \mathrm{dL}$ \\
\hline
\end{tabular}

\section{Methodology}

Methods using uricase, the enzyme that catalyses the oxidation of uric acid to allantoin are most specific. The simplest of these methods measures the differential absorption of uric acid and allantoin at $293 \mathrm{~nm} .{ }^{10}$ The difference in absorbance before and after incubation with uricase is proportional to the uric acid concentration. This method has been proposed as candidate reference method.11

This method was done in our study. This is the most specific method.

\section{Followup}

All the patients were followed up for a period of 7 days. During followup, any changes in Killip's classification, features of cardiac failure and any mortality were noted in both groups of patients. Routine daily physical examination was done. ECGs were taken daily and additional investigations carried out if necessary. Patients were discharged on $8^{\text {th }}$ day if they were stable, otherwise their hospital stay was prolonged.

Framingham criteria for heart failure like JVP elevation, basal rales, acute pulmonary oedema, S3 gallop, tachycardia ( $>100 / \mathrm{min}$.), lower extremity oedema were used in this study for making a diagnosis of CCF. ${ }^{12}$

\section{OBSERVATIONS AND RESULTS}

The study population consisted of 100 patients with 77 males and 23 females. All patients belonged to places around Warangal District. All patients were admitted in Intensive Cardiac Care Unit initially for 5 days, then cared in adjoining intermediate cardiac care ward and discharged after an average period of 7 days provided there were no complications. 
The various observations made in this study are depicted below.

\begin{tabular}{|c|c|c|c|c|c|}
\hline Age in Years & $\mathbf{3 1 - 4 0}$ & $\mathbf{4 1 - 5 0}$ & $\mathbf{5 1 - 6 0}$ & $\mathbf{6 1 - 7 0}$ & $\mathbf{7 1 - 8 0}$ \\
\hline No. of cases & 10 & 22 & 37 & 24 & 7 \\
\hline \multicolumn{6}{|c|}{ Table 1: Age Incidence } \\
\hline
\end{tabular}

\begin{tabular}{|c|c|c|}
\hline Sex & No. of Cases & Ratio \\
\hline Males & 77 & 3.34 \\
\hline Females & 23 & 1 \\
\hline \multicolumn{3}{|c|}{ Table 2: Sex Ratio } \\
\hline
\end{tabular}

\begin{tabular}{|c|c|c|}
\hline Sex & $\begin{array}{c}\text { Population with } \\
\text { Normal Uric Acid (53) }\end{array}$ & $\begin{array}{c}\text { Population with High } \\
\text { Uric Acid (47) }\end{array}$ \\
\hline Male & $43(81 \%)$ & $32(68 \%)$ \\
\hline Female & $10(19 \%)$ & $15(32 \%)$ \\
\hline \multicolumn{2}{|c|}{ Table 3: Population with Hyperuricaemia } \\
and Normouricaemia
\end{tabular}

\begin{tabular}{|c|c|c|c|c|c|c|}
\hline $\begin{array}{c}\text { Uric } \\
\text { Acid } \\
\text { (mg/dL) }\end{array}$ & 3.0-3.9 & 4.0-4.9 & 5.0-5.9 & 6.0-6.9 & 7.0-7.9 & 8.0-8.9 \\
\hline Male & 3 & 13 & 17 & 9 & 22 & 13 \\
\hline Female & 0 & 9 & 1 & 5 & 4 & 4 \\
\hline \multicolumn{7}{|c|}{ Table 4: Distribution of Patients According to } \\
Uric Acid Level \& Sex-in Total Population \\
\hline
\end{tabular}

\begin{tabular}{|c|c|c|}
\hline Killip Class & I \& II & III \& IV \\
\hline No. of Patients & 19 & 28 \\
\hline \multicolumn{3}{|c|}{ Table: 5: Killip Class in High Serum Uric Acid Population } \\
\hline
\end{tabular}

Percentage of patients with Killip I \& II in high serum uric acid population is $40 \%$.

Percentage of patients with high Killip class III \& IV in high SUA population is $60 \%$.

\begin{tabular}{|c|c|c|}
\hline Killip Class & I \& II & III \& IV \\
\hline No. of Patients & 40 & 13 \\
\hline \multicolumn{2}{|c|}{ Table 6: Killip Class in Normal } \\
Serum Uric Acid Population \\
\hline
\end{tabular}

Percentage of patients with Killip class I \& II in normal serum uric acid population $(40 \times 100 \div 53)$ is $75 \%$.

Percentage of patients with high Killip class III \& IV in normal serum uric acid population $(13 \times 100 \div 53)$ is $25 \%$.

\begin{tabular}{|c|c|}
\hline $\begin{array}{c}\text { Total No. of } \\
\text { Patients Studied }\end{array}$ & $\begin{array}{c}\text { No. of Patients who } \\
\text { Developed Heart Failure }\end{array}$ \\
\hline 100 & 41 \\
\hline Table 7: Incidence of & Heart Failure in Total Population \\
\hline
\end{tabular}

i.e. 41 of patients in the study developed heart failure.

\begin{tabular}{|c|c|c|}
\hline $\begin{array}{c}\text { Total No. of } \\
\text { Heart Failure Patients }\end{array}$ & Male (\%) & Female (\%) \\
\hline 41 & $33(80 \%)$ & $8(20 \%)$ \\
\hline \multicolumn{2}{|c|}{ Table 8: Heart Failure According to Sex } \\
\hline
\end{tabular}

\begin{tabular}{|c|c|c|c|}
\hline $\begin{array}{l}\text { Total No. of Patients } \\
\text { with Heart Failure }\end{array}$ & \multicolumn{2}{|c|}{$\begin{array}{l}\text { No. of Patients } \\
\text { with High Serum } \\
\text { Uric Acid }\end{array}$} & $\begin{array}{l}\text { No. of Patients } \\
\text { with Normal } \\
\text { Serum Uric Acid }\end{array}$ \\
\hline 41 & \multicolumn{2}{|c|}{30} & 11 \\
\hline \multicolumn{4}{|c|}{$\begin{array}{l}\text { Table 9: Proportion of Heart Failure Contributed by } \\
\text { Patients with High \& Normal Serum Uric Acid Level }\end{array}$} \\
\hline \multicolumn{4}{|c|}{$\begin{array}{l}\text { It is observed that patients with high uric acid leve } \\
\text { contribute } 73 \%(30 \times 100 \div 41) \text { to the total incidence of heart } \\
\text { failure whereas patients with normal uric acid contributes to } \\
27 \% \text { only. }\end{array}$} \\
\hline \multicolumn{2}{|c|}{$\begin{array}{l}\text { No. of Patients with High } \\
\text { Serum Uric Acid Level }\end{array}$} & \multicolumn{2}{|c|}{$\begin{array}{l}\text { No. of Patients with } \\
\text { Heart Failure }\end{array}$} \\
\hline \multicolumn{2}{|c|}{47} & \multicolumn{2}{|c|}{30} \\
\hline \multicolumn{4}{|c|}{$\begin{array}{l}\text { Table 10: Incidence of Heart Failure in } \\
\text { Patients with High Serum Uric Acid Level }\end{array}$} \\
\hline
\end{tabular}

i.e. $64 \%(30 \times 100 \div 47)$ of patients with high uric acid level developed heart failure.

i.e. $36 \%$ of patients with high uric acid level didn't develop heart failure.

\begin{tabular}{|c|c|}
\hline $\begin{array}{l}\text { No. of Patients with } \\
\text { Normal Serum }\end{array}$ & $\begin{array}{l}\text { No. of Patients with } \\
\text { Heart Failure }\end{array}$ \\
\hline 53 & 11 \\
\hline \multicolumn{2}{|c|}{$\begin{array}{l}\text { Table 11: Incidence of Heart Failure in } \\
\text { Patients with Normal Serum uric Acid Level }\end{array}$} \\
\hline
\end{tabular}

i.e. $21 \%$ of patients with normal uric acid level developed heart failure.

i.e. $79 \%$ of patients with normal uric acid level didn't develop heart failure.

\begin{tabular}{|c|c|c|}
\hline $\begin{array}{c}\text { Echo } \\
\text { Findings }\end{array}$ & $\begin{array}{c}\text { In High Uric } \\
\text { Acid }\end{array}$ & $\begin{array}{c}\text { In Normal Uric } \\
\text { Acid }\end{array}$ \\
\hline & Patients (n=47) & Patients (n=53) \\
\hline LVEF $<50 \%$ & $17(36 \%)$ & $8(15 \%)$ \\
\hline LVEF $>50 \%$ & $30(64 \%)$ & $45(85 \%)$ \\
\hline \multicolumn{2}{|c|}{ Table 12: Echocardiogram Analysis } \\
\hline
\end{tabular}

i.e. $36 \%$ of patients with hyperuricaemia and $15 \%$ of patients with normouricaemia had $\mathrm{LVEF}<50 \%$

\begin{tabular}{|c|c|}
\hline $\begin{array}{c}\text { Total No. of } \\
\text { Patients }\end{array}$ & $\begin{array}{c}\text { No. of Patients who } \\
\text { Developed Arrhythmias }\end{array}$ \\
\hline 100 & 7 \\
\hline \multicolumn{2}{|c|}{ Table 13: Incidence of Arrhythmias in Total } \\
Population
\end{tabular}

i.e, $7 \%$ of patients in this study developed arrhythmias.

\begin{tabular}{|c|c|c|}
\hline $\begin{array}{c}\text { No. of Patients with } \\
\text { Arrhythmias }\end{array}$ & Male \% & Female \% \\
\hline 7 & $6(86 \%)$ & $1(14 \%)$ \\
\hline \multicolumn{2}{|c|}{ Table 14: Arrhythmias According to Sex } \\
\hline
\end{tabular}

\begin{tabular}{|c|c|c|}
\hline $\begin{array}{c}\text { No. of Patients } \\
\text { with Arrhythmias }\end{array}$ & $\begin{array}{c}\text { No. of Patients } \\
\text { with High SUA }\end{array}$ & $\begin{array}{c}\text { No. of Patients } \\
\text { with Normal } \\
\text { SUA }\end{array}$ \\
\hline 7 & 5 & 2 \\
\hline $\begin{array}{c}\text { Table 15: Proportion of Arrhythmias Contributed by } \\
\text { Patients with High and Normal Serum Uric Acid Level }\end{array}$ \\
\hline
\end{tabular}


Contribution of patients with high serum uric acid level to arrhythmias: $71 \%$ Contribution of patients with normal serum uric acid levels to arrhythmias: $29 \%$.

It is observed that patients with high SUA level contribute $71 \%$ to the total incidence of arrhythmias.

\begin{tabular}{|c|c|}
\hline $\begin{array}{c}\text { No. of Patients with } \\
\text { High SUA }\end{array}$ & $\begin{array}{c}\text { No. of Patients with } \\
\text { Arrhythmias }\end{array}$ \\
\hline 47 & 5 \\
\hline \multicolumn{2}{|c|}{ Table 16: Incidence of Arrhythmias in } \\
Patients with high Serum Uric Acid Level
\end{tabular}

Incidence $(5 \times 100 \div 47)=11 \%$.

i.e. $11 \%$ patients with high uric acid level developed arrhythmias.

\begin{tabular}{|c|c|}
\hline $\begin{array}{l}\text { No. of Patients with } \\
\text { Normal Uric Acid }\end{array}$ & $\begin{array}{c}\text { No. of Patients } \\
\text { with Arrhythmias }\end{array}$ \\
\hline 53 & 2 \\
\hline \multicolumn{2}{|c|}{$\begin{array}{c}\text { Table 17: Incidence of Arrhythmias in Patients } \\
\text { with Normal Serum Uric Acid Level }\end{array}$} \\
\hline
\end{tabular}

Incidence $(2 \times 100 \div 53)=4 \%$.

i.e. $4 \%$ of patients with normal uric acid levels developed arrhythmias.

\begin{tabular}{|c|c|}
\hline $\begin{array}{c}\text { Total No. of } \\
\text { Patients Studied }\end{array}$ & $\begin{array}{c}\text { No. of } \\
\text { Patients Died }\end{array}$ \\
\hline 100 & 15 \\
\hline \multicolumn{2}{|c|}{ Table 18: Incidence of Mortality in Total Population } \\
\hline
\end{tabular}

i.e. $15 \%$ of patients in study died.

\begin{tabular}{|c|c|}
\hline Age (Years) & Total No. of Patients \\
\hline $41-50$ & 3 \\
\hline $51-60$ & 6 \\
\hline $61-70$ & 4 \\
\hline $71-80$ & 2 \\
\hline \multicolumn{2}{|c|}{ Table 19: Mortality in Age Group } \\
\hline
\end{tabular}

\begin{tabular}{|c|c|c|}
\hline Total No. of Deaths & Male (\%) & Female (\%) \\
\hline 15 & $14(93 \%)$ & $1(7 \%)$ \\
\hline \multicolumn{3}{|c|}{ Table 20: Mortality According to Sex } \\
\hline
\end{tabular}

\begin{tabular}{|c|c|c|}
\hline $\begin{array}{c}\text { Total No. of } \\
\text { Deaths }\end{array}$ & $\begin{array}{c}\text { No. of Patients } \\
\text { with High Uric } \\
\text { Acid Level }\end{array}$ & $\begin{array}{c}\text { No. of Patients with } \\
\text { Normal Uric } \\
\text { Acid Level }\end{array}$ \\
\hline 15 & 12 & 3 \\
\hline \multicolumn{2}{|c|}{ Table 21: Proportion of Mortality Contributed by } \\
Patients with High \& Normal Serum Uric Acid Level \\
\hline
\end{tabular}

It is observed that patients with high uric acid level contribute $80 \%$ to the total incidence of mortality $(12 \times 100 \div 15=80 \%)$ and patients with normal serum uric acid levels contribute $20 \%$ to the total incidence of mortality $(3 \times 100 \div 15=20)$.

\begin{tabular}{|c|c|}
\hline $\begin{array}{c}\text { No. of Patients with High } \\
\text { Serum Uric Acid Level }\end{array}$ & No. of Deaths \\
\hline 47 & 12 \\
\hline $\begin{array}{c}\text { Table 22: Incidence of Mortality in Patients } \\
\text { with High Serum Uric Acid Level }\end{array}$ \\
\hline
\end{tabular}

Incidence $(12 \times 100 \div 47)=26 \%$.

i.e. $26 \%$ of patients with high uric acid level died in the study.

\begin{tabular}{|c|c|}
\hline $\begin{array}{c}\text { No. of Patients with } \\
\text { Normal Uric Acid Level }\end{array}$ & No. of Deaths \\
\hline 53 & 3 \\
\hline \multicolumn{2}{|c|}{ Table 23: Incidence of Mortality in } \\
Patients with Normal Serum Uric Acid Level \\
\hline
\end{tabular}

Incidence $(3 \times 100 \div 53)=6 \%$.

i.e. $6 \%$ patients with normal uric acid level died in the study.

\section{DISCUSSION}

Total number of patients included in this study was 100, out of which 47 patients had elevated levels of uric acid above normal range and 53 patients had normal serum uric acid levels following acute myocardial infarction.

The significance level between two parameters is assessed with $\mathrm{p}$ value calculated by applying Chi-square test.

\section{Age}

Of the 100 patients, 10 patients were in the age group of 31-40 years, 22 patients were in the age group of 41-50 years, 37 patients were in the age group of 51-60 years, 24 patients were in the age group of $61-70$ years, 7 patients were in the age group of 71-80 years. (Table 1).

\section{The Results of Other Studies as Follows}

\begin{tabular}{|c|c|c|}
\hline Age in Years & High Uric Acid & Normal Uric Acid \\
\hline Present Study & 59.55 & 58.16 \\
\hline Agarwal S et al 13 & 60.59 & 58.90 \\
\hline
\end{tabular}

The mean ages in hyperuricaemic population and in normouricaemic population were 59.55 years, 58.16 years respectively in this study.

Present study results are comparable with Agarwal S et al study.

\section{Sex Ratio (Table 2)}

In this study, male and female ratios were 3.34:1, 2.12:1 and 4.2:1 in total population, hyperuricaemic population and normouricaemic population respectively.

\begin{tabular}{|c|c|c|}
\hline & High Uric Acid & Normal Uric Acid \\
\hline & Male $:$ Female & Male $:$ Female \\
\hline Present Study & $2.12: 1$ & $4.2: 1$ \\
\hline MY Nadkar et al $^{14}$ & $1.7: 1$ & $3.54: 1$ \\
\hline
\end{tabular}

Present study correlates with MY Nadkar et al study.

Population with Hyperuricaemia \& Population with Normouricaemia

Out of 100 patients studied, 53 patients had normal uric acid level and they were taken up as patients with normal serum uric acid. Of which $43(81 \%)$ were males and $10(19 \%)$ were females. The rest 47 patients had elevated serum uric acid level and they were taken up as patients with hyperuricaemia. of which $34(72.3 \%)$ were males and 13 (27.7\%) were females.

Both were compared with various outcomes. 
Distribution of Patients According to Serum Uric Acid Level \& Sex-in Total Population (Table 4)

In this study, the mean serum uric acid levels in males \& females were $6.25 \mathrm{mg} / \mathrm{dL} \& 5.98 \mathrm{mg} / \mathrm{dL}$ respectively. The mean serum uric acid levels in patients with high serum uric acid and in patients with normal uric acid were $7.48 \mathrm{mg} / \mathrm{dL}$ \& $4.94 \mathrm{mg} / \mathrm{dL}$ respectively. The mean serum uric acid in Shirisha Agarwal et al was $7.03 \mathrm{mg} / \mathrm{dL}, 5.77 \mathrm{mg} / \mathrm{dL}$ in hyperuricaemic and normouricaemic population respectively. So present study correlates with this study.

\section{Clinical Status-Killip Class \& Serum Uric Acid}

In this study, 23 patients presented with Killip class I, 36 patients presented with Killip class II, 18 patients presented with Killip class III, 23 patients presented with Killip class IV. Killip class III \& IV were taken as high risk category in this study and evaluated whether high uric acid concentration after myocardial infarction correlated with this high risk Killip class.

When clinical status of patients based on Killip class I to IV and uric acid were analysed, the following observations were made. In the patients with normal serum uric acid level, 75\% belonged to I \& II Killip class and only $25 \%$ belonged to Killip class III \&IV whereas in patients with hyperuricaemia, 40\% belonged to Killip class I \& II and $60 \%$ belonged to Killip class III \& IV (Table 5 \& 6).

The results of this study showed significant association between high serum uric acid levels and higher Killip class (III \&IV) of heart failure ( $\mathrm{p}<0.05)$.

Shoba Shetty et $\mathrm{al}^{15}$ showed that in patients with higher Killip class (III \& IV), there were high serum uric acid levels ( $p$ $<0.001$ ).

MY Nadkar, VI Jain et al also found similar results between high serum uric acid levels and higher Killip class (III \& IV).

Present study correlates with above studies and Kojima S, Sakamoto et al, (American Journal of Cardiology, 2005 Aug. 15) who also showed patients who had high uric acid level belonged to higher Killip class. Hence, uric acid can also be used as a predictor of prognosis.

\section{Heart Failure}

41 out of 100 patients in this study had heart failure in the post-myocardial infarction period. So the incidence of heart failure was $41 \%$. Of which 28 (68.2\%) were males, 13 (31.8\%) were females. (Table $7 \& 8$ ).

It was observed that among 41 heart failure patients, 30 patients had high uric acid level and 11 patients had normal uric acid level. So patients who had high uric acid level and normal uric acid level contributed to $73 \%$ and $27 \%$ respectively to heart failure (Table 9).

It was also found that 30 patients out of 47 patients with high uric acid level had heart failure amounting to an incidence of $64 \%$ heart failure in this group (Table 10 ).

While only 11 out of 53 patients with normal uric acid level had heart failure. i.e. only $21 \%$ of patients with normal uric acid level had heart failure (Table 11).

Present study correlates with other studies who showed similar findings and elevated serum uric acid level is an early predictor of short-term outcome.

The results of other studies are as follows.

\begin{tabular}{|c|c|c|c|}
\hline & $\begin{array}{c}\text { High } \\
\text { UA }\end{array}$ & $\begin{array}{c}\text { Normal } \\
\text { UA }\end{array}$ & $\begin{array}{c}\mathbf{P}^{*} \\
\text { value }\end{array}$ \\
\hline Present Study & $64 \%$ & $21 \%$ & $<0.01$ \\
\hline $\begin{array}{c}\text { Lichen, Xian Lu et } \\
\text { al16 }\end{array}$ & $48 \%$ & $16 \%$ & $<0.05$ \\
\hline \multicolumn{2}{|c|}{ Percentage of Heart Failure } \\
\hline
\end{tabular}

*Chi-square test

It shows there was significant association between raised serum uric acid levels and incidence of heart failure in patients with AMI ( $\mathrm{p}<0.05)$.

Kojima S, Sakamoto et al (American Journal of Cardiology 2005 Aug. 15), Anker SD, Doehner W et al (Circulation 2003, Apr. 22; circulation 2003 Nov. 25) Sakai H, Tsutamoto T et al (J cardiol.2006 May), Joshua M, Hare MD et al (Circulation 2003, American Heart Association), Virendra Singh, RK Goyal et al (Journal of the Indian Medical association 1977 Sep. 1) studies support this study. Their studies revealed that serum uric acid level reflects circulatory xanthine oxidase activity and oxidative stress production. Increased serum uric acid level has been identified in patients who have congestive cardiac failure and is a marker of poor prognosis in such patients.

\section{Echocardiogram}

In high uric acid population, 17 (36\%) patients had LVEF $<50 \%$ and $30(64 \%)$ patients had LVEF $>50 \%$ whereas in normal uric acid level population,

8 patients had LVEF $<50 \%$ and 45 patients had LVEF $>50 \%$ (Table 12).

Among 17 hyperuricaemia patients, 16 (85\%) are males and $9(53 \%)$ are females. Patients who had elevated serum uric acid level, hyperuricaemia is significantly associated with LVEF $<50 \%(\mathrm{p}<0.05)$.

\section{Results of other studies are as follows}

\begin{tabular}{|c|c|c|c|}
\hline & High SUA & Normal SUA & P* value \\
\hline Present study & $36.1 \%$ & $15.01 \%$ & $<0.05$ \\
\hline Lichen et al 16 & $36.4 \%$ & $15.1 \%$ & $<0.05$ \\
\hline \multicolumn{4}{|c|}{ LVEF <50\% (\%) } \\
\hline
\end{tabular}

${ }^{*}$ Chi-square test

Present study results are similar to results of reference study. So uric acid level can be used as a definite predictor of cardiac failure.

\section{Arrhythmias}

7 out of 100 patients developed arrhythmias in this study. So the incidence of arrhythmias was $7 \%$ of which 6 (86\%) were males, 1 (14\%) was female. 3 patients had ventricular tachycardia and 4 patients had supraventricular tachycardia (Table 13 \& 14).

It was observed that among 7 arrhythmias, 5 patients had high uric acid level and 2 patients had normal uric acid level. So patients who had high uric acid level and normal uric acid level contributed to $71 \%$ and $29 \%$ respectively to arrhythmias (Table 15).

It was also found that 5 patients out of 47 patients with high uric acid level had arrhythmias amounting to an incidence of $11 \%$ arrhythmias in this group while only 2 out of 53 patients with normal uric acid level had arrhythmias i.e. only $4 \%$ of patients with normal uric acid level had arrhythmias. (Table 16 \& 17). 
The above findings suggest that the occurrence of arrhythmias is also high in patients with high uric acid level. But hyperuricaemia was not significantly associated with development of arrhythmias in this study ( $p$ is 0.17939 (NS).

Results of other studies are shown below.

\begin{tabular}{|c|c|c|c|}
\hline & High SUA & Normal SUA & $P^{*}$ Value \\
\hline Present Study & $11 \%$ & $4 \%$ & $0.179(\mathrm{NS})$ \\
\hline $\begin{array}{c}\text { Lichen, Xian } \\
\text { et. al 16 }\end{array}$ & $10.9 \%$ & $6.5 \%$ & $0.509(\mathrm{NS})$ \\
\hline \multicolumn{3}{|c|}{ Percentage of Arrhythmias } \\
\hline
\end{tabular}

*chi-square test

This observation can be matched with the outcome of a large randomised double blind placebo control clinical trial "Oxypurinol therapy for CHF" conducted in 2003, which could establish a beneficial effect for oxypurinol in reducing the incidence of arrhythmias and other adverse cardiac events by lowering serum uric acid level.

The above studies \& present study tells there is a high incidence of arrhythmias when there is an elevated serum uric acid level and it is hypothetical an increased uric acid level may be arrhythmogenic. Further studies are needed to conclude it.

\section{MORTALITY}

15 out of 100 patients died due to their cardiac ailments in this study. This amounts to mortality rate of $15 \%$ of which 14 (93\%) were males, 1 (7\%) was female. (Table $18 \& 20)$.

Out of 15 deaths, 3 patients (20\%) were in the age group of 41-50 years, 6 patients (40\%) were in the age group of 5160 years, 4 patients $(27 \%)$ were in the age group of $61-70$ years, 2 patients (13\%) were in the age group of 71-80 years (Table 19).

To find out the prognostic significance of elevated uric acid level following acute myocardial infarction, mortality rate in patients with normal and high uric acid level were separately calculated.

It was observed that among 15 deaths, 12 deaths were contributed by patients with high uric acid levels and 3 deaths by those who had normal uric acid levels. Thus, $80 \%$ of deaths in post-infarction period occurred in those who had a high uric acid level and only $20 \%$ in those who had a normal uric acid level (Table 21).

It was also found that 12 out of 47 patients with high uric acid level died. This implies a mortality rate of $26 \%$ in patients with hyperuricaemia.

Likewise a mortality rate of $6 \%$ was observed for patients with normal uric acid level following myocardial infarction (Table 22 \& 23).

\begin{tabular}{|c|c|c|c|}
\hline & High SUA & Normal SUA & P* Value \\
\hline Present Study & $26 \%$ & $6 \%$ & $<0.05$ \\
\hline Lichen et al 16 & $5 \%$ & $0 \%$ & $<0.05$ \\
\hline \multicolumn{4}{|c|}{ Percentage of Mortality } \\
\hline
\end{tabular}

\section{${ }^{*}$ chi-square test}

This striking difference in the mortality figures for both group of patients implies uric acid level can be used as a predictor of mortality following myocardial infarction. The association between hyperuricaemia and mortality was found to be significant $(\mathrm{p}<0.05)$.

\section{CONCLUSION}

1. There is a significant association between elevated SUA and cardiac failure.

2. Patients with high SUA level belonged to higher Killip class (III \& IV).

3. Elevated uric acid level had an objective correlation with echocardiographic evaluation of LV dysfunction.

4. Elevated serum uric acid level may be arrhythmogenic. Further studies are needed to confirm it.

5. A high serum uric acid level correlated with short-term mortality in acute myocardial infarction.

6. Measuring serum uric acid level is one of the predictable prognostic indicator in acute myocardial infarction and one of the early and short-term predictor.

Till date several studies have evaluated the predictive value of on admission serum uric acid and its outcomes in AMI; it has been shown to have an adverse effect in short and long term in patients with AMI. There are many developed countries that are using pharmacoinvasive approach for their AMI system of care (Fibrinolytic treatment in pre-hospital setting with an Invasive procedure backup), but in developing countries like India, serum uric acid is an economical biomarker that is readily, quickly and reliably obtainable and thus, along with Killip's classification, should be incorporated for risk stratification in patients with AMI.

\section{REFERENCES}

1. Rogers WJ, Canto JG, Lambrew CT, et al. Temporal trends in the treatment of over 1.5 million patients with myocardial infarction in the US from 1990 through 1999: the national registry of myocardial infarction 1,2 \& 3 . J Am Coll Cardiol 2000;36(7):2056-63.

2. Kesteloot H, Sans S, Kromhout D. Evolution of all causes and cardio vascular mortality in the age group of the 75 to 84 years in Europe during the period 1970-1996: a comparison with worldwide changes. Eur Heart J 2002;23(5):384-98.

3. Carmeliet E. Cardiac ionic currents and acute ischemia: from channels to arrhythmias. Physiol Rev 1999;79(3):917-1017.

4. Thompson CA, Yarzebski J, Goldberg RT, et al. Changes over time in the incidence \& case-fatality rates of primary ventricular fibrillation complicating acute myocardial infarction: perspectives from the Worcester heart attack study. Am Heart J 2000;139(6):1014-21.

5. Hochman JS. Cardiogenic shock complicating acute myocardial infarction: expanding the paradigm. Circulation 2003;107(24):2998-3002.

6. Bertrand ME, McFadden E. Cardiogenic shock: is there light at the end of tunnel? J Am College cardiology 2003;42(8):1387-8.

7. Lewis EF, Moye LA, Rouleau JL, et al. Predictors of late development of heart failure in stable survivors of myocardial infarction: the CARE study. J Am College Cardiology 2003;42(8):1446-53.

8. Ridker PM, Morrow DA. C-reactive protein, inflammation and coronary risk. Cardiol Clin 2003;21(3):315-25.

9. Lek P, Nunez CA, Domanski L, et al. Malonyl dialdehyde, uric acid and white cell count as markers of oxidative stress in acute myocardial infarction and acute coronary insufficiency. J Clin Pharm Ther 1998;23(1):25-9. 
10. Feichtmeier TV, Wrenn HT. Direct determination of uric acid using uricase. Am J Clinic Pathol 1955;25:833-9.

11. Duncan PH, Gochman N, Cooper T, et al. A candidate reference method for uric acid in serum. I. Optimization \& evaluation. Clin Chem 1982;28(2):284-90.

12. Ho KKL, Anderson KM, Kannel WB, et al. Survival after the onset of congestive heart failure in Framingham heart study subjects. Circulation 1993;88(1):107-15.

13. Agarwal S, Aundhkar SC, Patanye A, et al. Evaluate the role of serum uric acid in acute myocardial infarction as a prognostic marker. Int J Health Sci Res 2014;4(5):120-8.
14. Nadkar MY, Jain VI. Serum uric acid in acute myocardial infarction. JAPI 2008;56(10):759-62.

15. Shetty SS, Rao AH, Kumar AKS, et al. Serum uric acid as a prognostic bio marker and its correlation with Killip class in AMI. Int J of Bio Medical Research 2013:4(7).

16. Chen L, Xian-Lun L, Qiao W, et al. Serum uric acid in patients with ST-elevation myocardial infarction. World J Emerg Med 2012;3(1):35-9. 